\title{
Ceviz Kabuğunun Karbonizasyonu ile Elde Edilen Katı Ürününün Toprak Düzenleyicisi Olarak Kullanılması
}

\section{Using of Solid Product Obtained by Carbonization of Walnut Shell as Soil Amendment}

\author{
Elif Yaman ${ }^{1 *}$, Esin Apaydın-Varol ${ }^{2}$, Hüseyin Tevfik Gültaş ${ }^{3}$, Nurgül Özbay ${ }^{4}$ \\ Geliş / Received: 29/05/2019 \\ Revize / Revised: 26/07/2019 \\ Kabul / Accepted: 08/09/2019
}

$\ddot{O}$ z- Biyokütlenin oksijensiz ortamda bozundurulması ile elde edilen piroliz katı ürünü (biyoçar), toprak kalitesini iyileştirici özelliğinden dolayı toprak düzenleyicisi olarak kullanılabilmektedir. Yapılan bu çalışmada, ceviz kabuğundan $500{ }^{\circ} \mathrm{C}^{\prime}$ de biyoçar elde edilmiş ve biyoçar $(\mathrm{g})$ :toprak (kg) oranı 5, 10 ve 20 olmak üzere üç farklı oranda biyoçar-toprak karışımları hazırlanmıştır. Elde edilen karışımlar 3, 8 ve 12 haftalık sürelerde inkübasyona bırakılmış ve inkübasyon sonunda toprak örneklerinin karakterizasyonu için pH, elektriksel iletkenlik, katyon değiştirme kapasitesi (KDK) ve su tutma kapasitesi (STK) ölçümleri yapılmıştır. Taramalı Elektron MikroskobuEnerji-Dağılımlı X-Işını (SEM-EDX) tekniği ile inorganik madde miktarı ve Kjeldahı metodu ile azot miktarı belirlenmiştir. Yüksek karbon içeriğine ve gözenekli yapıya sahip olan biyoçar, toprağın elektriksel iletkenlik ve pH değerlerini önemli ölçüde azaltırken, azot miktarını ise artırmıştır. Toprak için su tutma kapasitesi yaklaşık $0.55 \mathrm{~g} / \mathrm{g}$ olarak belirlenirken, biyoçar-toprak karışımında bu değerin $0.60 \mathrm{~g} / \mathrm{g}$ 'a yükseldiği görülmektedir. Biyoçarın bitki büyüme üzerindeki etkisi incelendiğinde, en verimli sonucun biyoçar (g):toprak (kg) oranının 5 olduğu örnekten elde edildiği belirlenmiştir.

Anahtar Kelimeler- Biyokütle, Biyoçar, Ceviz Kabuğu, Toprak, pH

bstract- Biomass can be used as a soil conditioner due to its soil quality enhancing properties. In this study, walnut shell biochar was produced at $500{ }^{\circ} \mathrm{C}$ and mixed with three different doses of soil, including biochar (g):toprak (kg) ratio are 5, 10 and 20. The obtained soil-biochar mixtures were incubated for 3,8 and 12 weeks. Electrical conductivity, pH measurements, cation exchange capacity (CEC) and water holding capacity (WHC) were carried out to characterize soil samples at the end of incubation periods. The amount of nitrogen was determined by Kjeldahl method and Scanning Electron Microscope-Energy-Dispersive X-Ray (SEM-EDX) was used to specify the amount of inorganic substance in soil. The biochar with high carbon content and porous structure significantly reduced the $\mathrm{pH}$ and electrical conductivity values of the soil and increased the nitrogen amount. While the water holding capacity for the soil is determined as approximately $0.55 \mathrm{~g} / \mathrm{g}$, it is seen that this value increases to $0.60 \mathrm{~g} / \mathrm{g}$ in the biochar-soil mixture. When the effect of biochar on plant growth was examined, it was determined that the most efficient result was obtained from $5 \mathrm{~g}$ of biochar/1 $\mathrm{kg}$ soil mixture.

Keywords- Biomass, Biochar, Walnut Shell, Soil, pH

\footnotetext{
1*Sorumlu yazar iletişim: elif.yaman@bilecik.edu.tr (https://orcid.org/0000-0002-1052-8779)

Merkezi Araştırma Laboratuvarı, Bilecik Şeyh Edebali Üniversitesi, Bilecik.

2İletişim: eapaydin@eskisehir.edu.tr (https://orcid.org/0000-0003-3468-3578)

Kimya Mühendisliği, Eskişehir Teknik Üniversitesi, Eskişehir.

3̇letişim: huseyin.gultas@bilecik.edu.tr (https://orcid.org/0000-0002-4987-8522)

Biyosistem Mühendisliği, Bilecik Şeyh Edebali Üniversitesi, Bilecik.

4İletişim:nurgul.ozbay@bilecik.edu.tr (https://orcid.org/ 0000-0002-0666-3417)

Kimya Mühendisliği, Bilecik Șeyh Edebali Üniversitesi, Bilecik.
} 


\section{GİRIŞ}

Toprak, mineraller, organikler, gazlar, sıvılar ve yaşayan organizmaların oluşturduğu doğal bir ekosistemdir [1]. Toprağın sağlıklı olması, bitki ve hayvan verimliliğini ve biyolojik çeşitliliği sürdürmek, su ve hava kalitesini korumak, insan sağlığını ve habitatını iyileştirmek için oldukça önemlidir [2]. Çoğu bitkinin büyümesi, toprak sağlığına bağlıdır. Toprak, sıkışma, tuzlanma, asitlenme ve alkalileşme gibi kötü etkiler altında ise tarımsal üretim için uygun değildir [3].

İnsan kökenli aktiviteler sonucunda sentetik organik bileşikler ve ağır metaller gibi kirleticiler de topraklara karışmakta ve toprak sağlığını olumsuz etkilemektedir [4]. Sorunlu toprakların iyileştirilmesi için pek çok yöntem önerilmiş ve geliştirilmiştir [5, 6]. Bu amaçla sürdürülebilir bir kaynak olan biyokütleden elde edilen biyoçarın kullanılması gelecek vaat etmektedir.

Biyokütlenin karbonizasyonu sonucu elde edilen biyoçar, karbon, hidrojen, oksijen ve çeşitli inorganik türler içerir [7]. Günümüzde toprakta biyoçar uygulamalarının artmasıyla birlikte sürdürülebilir tarım hedeflenmektedir [8]. Biyoçar toprakta kendi ağırlığının 6 katı kadar su tutar, fosfor ve azot gibi elementlerin topraktan bitkiler tarafından daha kolay alınabilmesini sağlar, yüzeyindeki fonksiyonel gruplar topraktaki katyonik faaliyetleri artırır ve böylece toprak; kalsiyum, magnezyum ve potasyum gibi besinleri tutar [9]. Güçlü alkalinitesi, geniş gözenek yapısı [10], yüksek özgül yüzey alanı, fiziksel ve biyolojik stabilitesinin iyi olması, biyoçarın toprak asitliğini iyileştirmesine olanak sağlar [11]. Ayrıca biyoçar uygulaması toprak gözenekliliğini, çekme dayanımını $[12,13]$ ve toprağın su tutma kapasitesini artırır $[14,15]$. Yapılan çalışmalar toprağa biyoçar eklenmesinin toprak organik karbonunun (SOC), toplam azotun, fosforun ve amonyumun arttırilmasinda iyileştirici etkileri olduğu göstermektedir [16]. Ayrıca azot çevrimine katkıda bulunarak, $\mathrm{N}_{2} \mathrm{O}$ emisyonunu ve azot kaybını azaltmakta ve toprağın besin maddelerinin tutulma oranını da arttırmaktadır [17].

Yapılan bu çalışmada, gıda endüstrisi atığı olarak temin edilen ceviz kabuğu karbonizasyon sürecine tabi tutulmuş, elde edilen biyoçarın toprak iyileştiricisi olarak kullanılması araştırılmıştır. Süreç parametreleri olarak, biyoçar: toprak oranı ve inkübasyon süresi denenmiş ve elde edilen sonuçlardan optimum değerlerde bitki büyüme testleri gerçekleştirilmiştir.

\section{DENEYSEL ÇALIŞMA}

Biyoçarın elde edilmesi, biyoçar-toprak karışımlarının hazırlanması ve bunların karakterizasyonları ile bitki büyüme deneyleri bu kısım altında verilmiştir.

\section{A. Biyoçarın Elde Edilmesi ve Karakterizasyonu}

Parçacık boyutu küçültülen ceviz kabuğu örnekleri toprak kap içerisinde ve ağzı kapatılarak $20^{\circ} \mathrm{C} / \mathrm{dk}$ 1sıtma hızı ile $500{ }^{\circ} \mathrm{C}$ 'ye çıkarılan kül fırınına yerleştirilmiş, $500^{\circ} \mathrm{C}$ 'de 15 dakika firında bekletilen örnek karakterizasyona hazır hale getirilmiştir (Şekil 1).

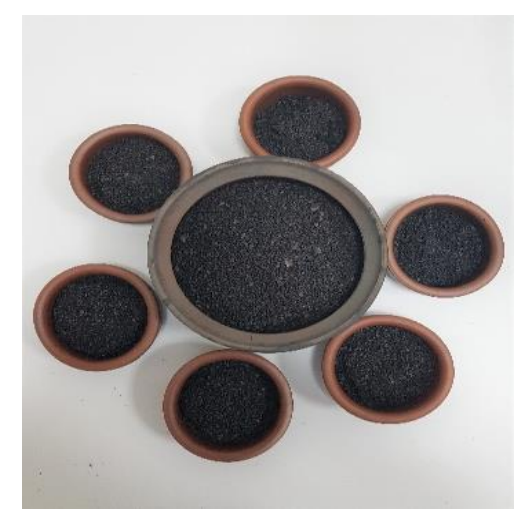

Şekil 1. Kül firınında üretilen biyoçar örnekleri

Elde edilen biyoçarın ve toprağın içerdiği azot, karbon, hidrojen ve oksijen miktarı elementel analiz cihazı (LECO, CHN/S 628) kullanılarak belirlenmiştir. Biyoçarın sahip olduğu fonksiyonel gruplar FT-IR spektrometresi (Perkin Elmer, Spektrum 100) ile $4000-380 \mathrm{~cm}^{-1}$ dalga boyu aralığında, $0,4 \mathrm{~cm}^{-1}$ çözünürlük ile zayıf toplam 
frekans (ATR) modülü kullanılarak belirlenmiştir. Biyoçarın morfolojik özelliklerinin belirlenmesi amacı ile taramalı elektron mikroskobu (SEM) (ZEISS, SUPRA 40VP) kullanılmıştır. Biyoçarın iletkenliğinin sağlanması için altın/paladyum karışımı ile kaplama işlemi uygulanmıştır. Kaplama cihazında (Quorum, Q300 model) altın/paladyum kaynağı altında 1 dakika boyunca kaplanan örneklerin kaplama kalınlığı yaklaşık $100 \mathrm{~nm}$ 'dir. Biyoçara uygulanan SEM analizinde, $15 \mathrm{kV}$ hızlandırma voltajı (EHT), $\sim 10 \mathrm{~mm}$ çalışma mesafesi (WD) ve ikincil elektron (SE) görüntüleme yöntemi kullanılmıştır.

\section{B. Biyoçar-Toprak Karışımlarının Hazırlanması ve Karakterizasyonu}

Çalışmada kullanılan toprak örneği Bilecik Şeyh Edebali Üniversitesi Ziraat ve Doğa Bilimleri Fakültesi Uygulama ve Araştırma Alanından temin edilmiş olup, elementel analiz sonuçlarına göre \%3,96 C, \%0,97 H ve \%95,07 O içermektedir. Biyoçar (g):toprak (kg) oranı 5, 10 ve 20 olmak üzere üç farklı oranda biyoçar-toprak karışımları hazırlanmıştır. Hazırlanan karışımlar 3, 8 ve 12 haftalık sürelerde inkübasyona bırakılmıştır. pH ve elektriksel iletkenlik ölçümlerinden önce hazırlanan biyoçar-toprak karışımlarından $5 \mathrm{~g}$ alınarak $100 \mathrm{~mL}$ saf su eklendikten sonra 24 saat bekletilmiştir. Hazırlanan örneklerin $\mathrm{pH}$ ve elektriksel iletkenlik değerleri $\mathrm{pH}$ metre (Mettler Toledo-Seven Compact) ve elektriksel iletkenlik cihazı (Hanna Instruments-Dist 4) kullanılarak belirlenmiştir.

Katyon değişim kapasitesi amonyum asetat yöntemi ile Gıda, Tarım ve Hayvancılık Bakanlığı, Tarımsal Araştırmalar ve Politikalar Genel Müdürlüğü, Eskişehir Geçit Kuşağı Tarımsal Araştırma Enstitüsü’nde gerçekleştirilmiştir.

Biyoçar uygulamasının toprak su tutma kapasitesi (STK) üzerindeki etkisini test etmek için, toprak, biyoçar ve toprak-biyoçar karışımlarının STK'sı belirlenmiştir. Su tutma kapasitesi tayini yapılacak örnekler, gözeneklerin açılması ve nemin uzaklaştırılması için etüvde $105^{\circ} \mathrm{C}$ 'de 48 saat bekletilmiştir. Aynı şekilde nemi uzaklaştırılan Kontes cam kolonlar $(2,5 \mathrm{~cm}$ i.ç.X10 cm) su tutma kapasitesi tayininde kullanılmıştır. Örnek su ile doyurulduktan sonra, 24 saat boyunca oda sıcaklığında bekletilmiş, 0,7 bar vakum basıncı ile susuzlaştırılmış ve ardından sabit tartıma gelene kadar etüvde $40 \pm 2{ }^{\circ} \mathrm{C}$ 'de kurutulmuştur. Örnek tarafından tutulan su miktarı Eşitlik1 ile belirlenmiştir $[18,19]$.

$\%$ Su tutma kapasitesi $($ WHC $)=($ Tutulan su $(\mathrm{g})) /($ Kuru örnek $(\mathrm{g})) \times 100$

Biyoçar miktarının ve bekletme süresinin toplam azot miktarına etkisi Kjeldahl metodu ile toprak içerisindeki inorganik elementlere etkisi ise SEM-EDX tekniği ile belirlenmiştir.

\section{Biyoçarın Bitki Büyüme Deneylerinde Test Edilmesi}

12 haftalık inkübasyon süresi sonunda bu biyoçar-toprak karışımları $1 \mathrm{~kg}$ kapasiteli saksılara alınarak, bu saksılara roka bitkisi ekilmiştir. Her bir saksıya 10'ar tohum atılmış, gübre desteği verilmemiş ve 3 tekerrürlü bir çalışma gerçekleştirilmiştir. Roka bitkisinin gelişiminin takibi her bitkiden 25. gün sonunda alınan 5 adet yaprağın en ve boy ölçümleri alınarak gerçekleştirilmiştir [20].

\section{SONUÇLAR VE TARTIŞMA}

Biyoçar karakterizasyon sonuçları, biyoçar-toprak karışımlarının karakterizasyon sonuçları ve bitki büyüme deneylerinden elde edilen sonuçlar bu bölüm altında karşılaştırılmalı olarak verilmiştir.

\section{A. Biyoçar Karakterizasyonu}

Biyoçarın elementel analiz sonuçları Tablo 1'de verilmiştir. Biyokütlenin karbon miktarı önceki çalışmalarda kütlece \%47,5 olarak belirlenmiş iken [21] biyoçarın karbon miktarı kütlece \%83,51 olarak belirlenmiş ve karbon miktarı karbonizasyon işlemi sonrasında yaklaşık \% 75 arttı̆̆ belirlenmiştir.

Tablo 1. Biyoçarın elementel analiz sonuçları (Alındığı gibi)

\begin{tabular}{lllll}
\hline & $\mathrm{C}$ & $\mathrm{H}$ & $\mathrm{N}$ & $\mathrm{O}^{*}$ \\
\hline Ceviz Kabuğu & 47,5 & 6,39 & 0,46 & 45,65 \\
Biyoçar & 83,51 & 4,39 & 0,12 & 11,98 \\
\hline * Farktan hesaplanmıștır. & & &
\end{tabular}


Biyoçarın FTIR spektrumu Şekil 2'de verilmiştir. FT-IR spektrumu incelendiğinde, $3500-3400 \mathrm{~cm}^{-1}$ dalga boyu civarında hidroksil (-OH) gruplarının varlığından kaynaklanan pik yer almaktadır. Ardından $3200-2800 \mathrm{~cm}^{-}$ 1 arasında ise alifatik (C-H) gerilim titreşimlerine ait pikler görülmektedir. $1600-1500 \mathrm{~cm}^{-1}$ arasında yer alan titreșimler biyoçar yapısında karbonil gruplarının $(\mathrm{C}=\mathrm{O})$ yani keton ve aldehitlerin varlığını göstermektedir. 1180 $\mathrm{cm}^{-1}$ dalga boyunda oluşan belirgin pik birincil alkollerdeki C-O deformasyonuna ve aromatik halkadaki C-H titreşimini göstermektedir. Biyoçarın yüzey yükü içerdiği alifatik, aromatik ve karboksil grupları gibi fonksiyonel gruplara bağlıdır. Yapıdaki karboksil grupları, besinlerin veya ağır metallerin adsorpsiyonu veya desorpsiyonu için ana iyon değişim bölgeleridir ve toprak uygulamalarında pH tamponlamada önemli rol oynarlar [4].

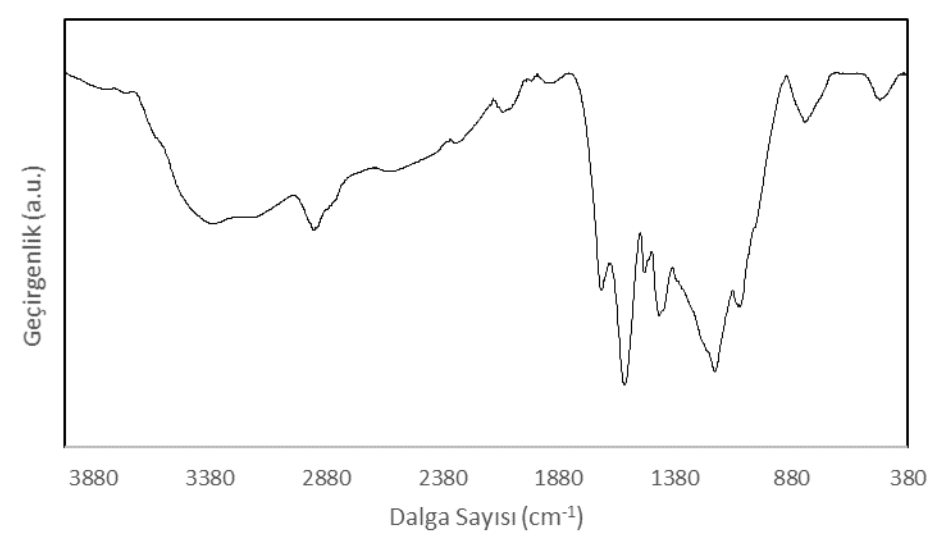

Şekil 2. Biyoçar FTIR spektrumu

Biyoçarın SEM analizinden elde edilen morfolojik görüntüsü Şekil 3'de verilmiştir. Ceviz kabuğuna uygulanan 1sıl işlem sonucunda, gözenekliliğin ve yüzey pürüzlülüğünün arttığı karbonizasyon işlemi sonucunda yüzeyde makro boyutta gözeneklerin oluştuğu gözlenmiştir.

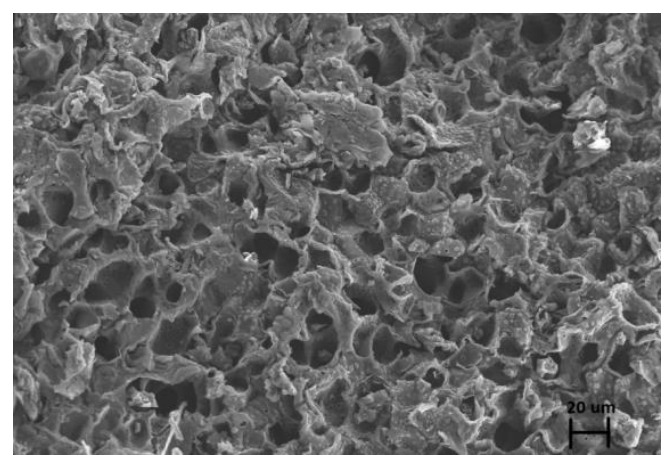

Şekil 3. Biyoçar SEM görüntüsü (1000X yakınlaştırma)

\section{B. Biyoçar-Toprak Karışımlarının Karakterizasyonu}

Toprak ve biyoçar örneklerinin elektriksel iletkenlik $(\mathrm{mS})$ ve $\mathrm{pH}$ değerlerinin değişimi inkübasyon süresi ve biyoçar:toprak oranına göre Tablo 2'de verilmiştir. 8. haftaya kadar inkübasyon süresi elektriksel iletkenlik üzerine oldukça etkiliyken, 8. haftadan sonra inkübasyon süresinin elektiriksel iletkenlik üzerine çok büyük etkisinin olmadığı görülmüştür. Biyoçar-toprak karışımlarının $\mathrm{pH}$ değerleri ise inkübasyon süresinden bağımsız olduğu belirlenmiş̧tir. 
Elif Yaman, Esin Apaydın-Varol, Hüseyin Tevfik Gültaş, Nurgül Özbay / BŞEÜ Fen Bilimleri, 6. Cilt - Prof. Dr. Fuat SEZGIN Bilim Y1lı Özel Sayısı, 106-116, 2019

Tablo 2. Toprak- biyoçar örneklerinin elektriksel iletkenlik ve pH değerleri

\begin{tabular}{lrrrrrr}
\hline Biyoçar (g): Toprak (kg) oranı & \multicolumn{3}{c}{ Elektriksel İletkenlik $(\mathrm{mS})$} & $\mathrm{pH}$ \\
& 3. hafta & 8. hafta & 12. hafta & 3. hafta & 8. hafta & 12. hafta \\
\hline $0: 1$ & 0,52 & 0,52 & 0,52 & 7,47 & 7,47 & 7,47 \\
$5: 1$ & 0,44 & 0,18 & 0,19 & 7,42 & 7,34 & 7,45 \\
$10: 1$ & 0,41 & 0,12 & 0,15 & 7,10 & 7,17 & 7,12 \\
$20: 1$ & 0,44 & 0,15 & 0,19 & 7,04 & 7,08 & 7,11 \\
\hline
\end{tabular}

Biyoçar miktarı ve inkübasyon süresinin elektriksel iletkenlik ve pH üzerine etkisi MINITAB V.8 yazılım programı kullanılarak yapılan varyans analizi ile belirlenmiştir. Çalışmada elde edilen elektriksel iletkenlik ve $\mathrm{pH}$ değerlerine ilişsin varyans analiz sonuçları ve Tukey testi sonuçları sırası ile Tablo 3, 4, 5 ve 6'da verilmiştir. Toprağa biyoçar eklenmesinin elektriksel iletkenlik üzerine etkisi incelendiğinde; biyoçar miktarına kıyasla inkübasyon süresinin istatistiksel açıdan $\mathrm{p}<0,05$ düzeyinde daha önemli olduğu belirlenmiştir. $\mathrm{pH}$ değerlerine ait varyasyon analizi sonuçları incelendiğinde ise, toprağa biyoçar eklenmesi ve inkübasyon süresinin $p<0,05$ düzeyinde önemli olmadı ̆̆ı görülmüştür.

Tablo 3. Elektriksel iletkenlik değişimi için yapılan varyans analiz sonuçları

\begin{tabular}{lccccc}
\hline Varyasyon kaynağı & $\begin{array}{c}\text { Serbestlik } \\
\text { derecesi }\end{array}$ & $\begin{array}{l}\text { Kareler } \\
\text { toplamı }\end{array}$ & $\begin{array}{c}\text { Kareler } \\
\text { ortalaması }\end{array}$ & F & P \\
\hline Biyoçar Miktarı & 3 & 0,440831 & 0,146944 & 150,28 & 0,000 \\
Hafta & 2 & 0,283489 & 0,141744 & 144,97 & 0,000 \\
Tekerrür & 2 & 0,000356 & 0,000178 & 0,18 & 0,835 \\
Biyoçar & 6 & 0,103711 & 0,017285 & 17,68 & 0,000 \\
Miktarı*Hafta & & & & & \\
Hata & 22 & 0,021511 & 0,000978 & & \\
Genel & 35 & 0,849897 & & &
\end{tabular}

Tablo 4. Biyoçar miktarı ve inkübasyon süresinin elektriksel iletkenlik değerlerine etkisi üzerine Tukey testi sonuçları

\begin{tabular}{lcccccc}
\hline Biyoçar Miktarı*Hafta & N & Ortalama & & Tukey grubu \\
\hline $0 * 3$ & 3 & 0,520000 & A & & & \\
$0 * 2$ & 3 & 0,520000 & A & & & \\
$0 * 8$ & 3 & 0,520000 & A & & & \\
$5 * 3$ & 3 & 0,440000 & A & B & & \\
$20 * 3$ & 3 & 0,440000 & A & B & & \\
$10 * 3$ & 3 & 0,410000 & & B & & \\
$20 * 12$ & 3 & 0,256667 & & & C & \\
$10 * 12$ & 3 & 0,200000 & & & C & D \\
$5 * 12$ & 3 & 0,186667 & & C & D \\
$5 * 8$ & 3 & 0,186667 & & C & D \\
$20 * 8$ & 3 & 0,150000 & & & D \\
$10 * 8$ & 3 & 0,126667 & & & D \\
\hline
\end{tabular}


Elif Yaman, Esin Apaydın-Varol, Hüseyin Tevfik Gültaş, Nurgül Özbay / BŞEÜ Fen Bilimleri, 6. Cilt - Prof. Dr. Fuat SEZGIN Bilim Y1lı Özel Sayısı, 106-116, 2019

Tablo 5. pH değişimi için yapılan varyans analiz sonuçları

\begin{tabular}{lccccc}
\hline Varyasyon kaynağı & $\begin{array}{c}\text { Serbestlik } \\
\text { derecesi }\end{array}$ & $\begin{array}{c}\text { Kareler } \\
\text { toplamı }\end{array}$ & $\begin{array}{c}\text { Kareler } \\
\text { ortalaması }\end{array}$ & F & P \\
\hline Biyoçar Miktarı & 3 & 0,5963 & 0,1988 & 1,59 & 0,220 \\
Hafta & 2 & 0,5540 & 0,2770 & 2,22 & 0,133 \\
Tekerrür & 2 & 0,2497 & 0,1248 & 1,00 & 0,385 \\
Biyoçar Miktarı*Hafta & 6 & 0,9416 & 0,1569 & 1,25 & 0,318 \\
Hata & 22 & 2,7510 & 0,1250 & & \\
Genel & 35 & 5,0926 & & & \\
\hline
\end{tabular}

Tablo 6. Biyoçar miktarı ve inkübasyon süresinin $\mathrm{pH}$ değerlerine etkisi üzerine Tukey testi sonuçları

\begin{tabular}{llrl}
\hline Biyoçar Miktarı*Hafta & N & \multicolumn{1}{c}{ Ortalama } & Tukey grubu \\
\hline $0 * 3$ & 3 & 7,48333 & A \\
$0 * 2$ & 3 & 7,47667 & A \\
$0 * 8$ & 3 & 7,47000 & A \\
$5 * 3$ & 3 & 7,47000 & A \\
$20 * 3$ & 3 & 7,47000 & A \\
$10 * 3$ & 3 & 7,42333 & A \\
$20 * 12$ & 3 & 7,32000 & A \\
$10 * 12$ & 3 & 7,31000 & A \\
$5 * 12$ & 3 & 7,24667 & A \\
$5 * 8$ & 3 & 7,10333 & A \\
$20 * 8$ & 3 & 7,04000 & A \\
$10 * 8$ & 3 & 6,65000 & A \\
\hline
\end{tabular}

Toprak ve biyoçar örneklerinin katyon değiştirme kapasitesi değerleri Tablo 7’te verilmiştir. Toprağın KDK değeri 19,55 meq $/ 100 \mathrm{~g}$ toprak, biyoçarın KDK değeri ise 9,22 meq $/ 100 \mathrm{~g}$ toprak olarak belirlenmiştir.

Tablo 7. Toprak ve biyoçar örneklerinin katyon değiştirme kapasitesi değerleri

\begin{tabular}{lc}
\hline & $\begin{array}{c}\text { Katyon değiştirme } \\
\text { kapasitesi } \\
\\
\end{array} \mathrm{m}_{\mathrm{eq}} / 100 \mathrm{~g}$ toprak $)$ \\
\hline Toprak & $19,55 \pm 0,89$ \\
Biyoçar & $9,22 \pm 0,42$ \\
\hline
\end{tabular}

Biyoçarın toprağa eklenmesi, toprağın dokusal ve yapısal özelliklerini etkileyerek su tutma kapasitesini değiştirir. Biyoçar mikrogözenekli yapısı sayesinde, bitki büyümesi için gerekli olan suyu depolayabilir ve dolayısıyla toprak su tutma kapasitesini arttırabilir. Şekil 4'te biyoçar, toprak ve biyoçar-toprak karışımlarının su tutma kapasiteleri verilmiştir. Toprak için su tutma kapasitesi yaklaşık 0,55 g/g olarak belirlenirken, biyoçar eklenen toprakta bu değer $0,60 \mathrm{~g} / \mathrm{g}$ 'a yükselmiştir. 
Elif Yaman, Esin Apaydın-Varol, Hüseyin Tevfik Gültaş, Nurgül Özbay / BŞEÜ Fen Bilimleri, 6. Cilt - Prof. Dr. Fuat SEZGIN Bilim Y1lı Özel Sayısı, 106-116, 2019

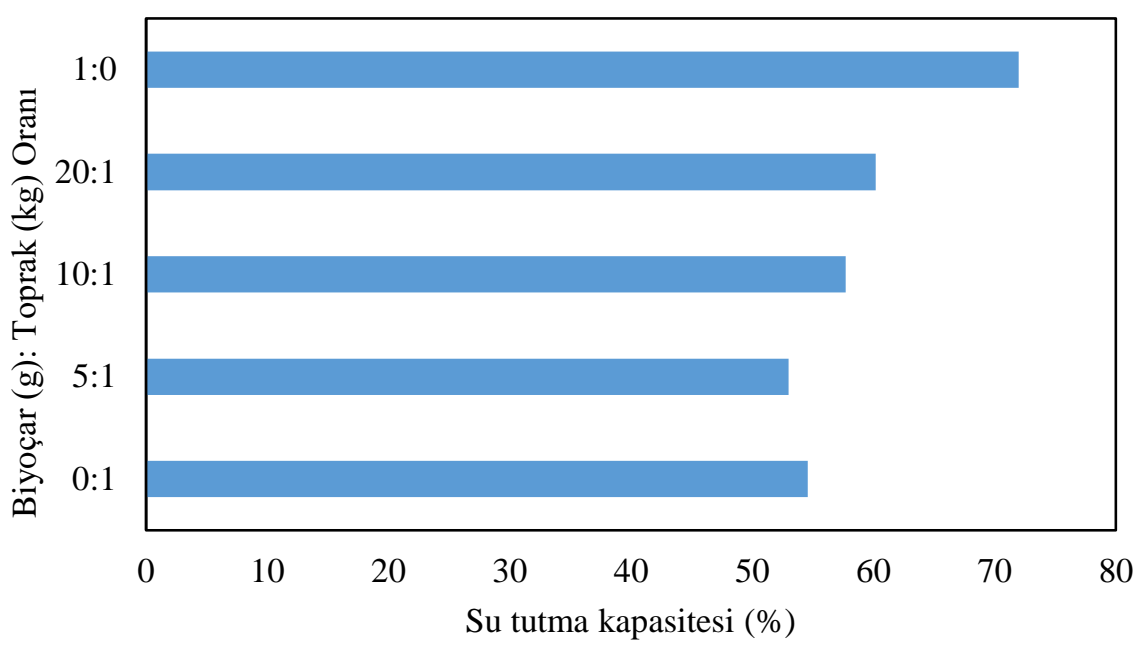

Şekil 4. Biyoçar uygulamasının toprak su tutma kapasitesine etkisi

Biyoçar:toprak oranının 5 olduğu örneğin 12. hafta sonundaki EDX spektrumu Şekil 5'de verilirken, EDX analizinden elde edilen inorganik bileşenlerin miktarı inkübasyon süresine göre sırası ile Şekil 6, Şekil 7 ve Şekil 8 'de verilmiştir. Biyoçar, geniş yüzey alanı, yüksek gözenek hacmi ve sahip olduğu fonksiyonel gruplar sayesinde iyi bir metal adsorbanıdır [6].

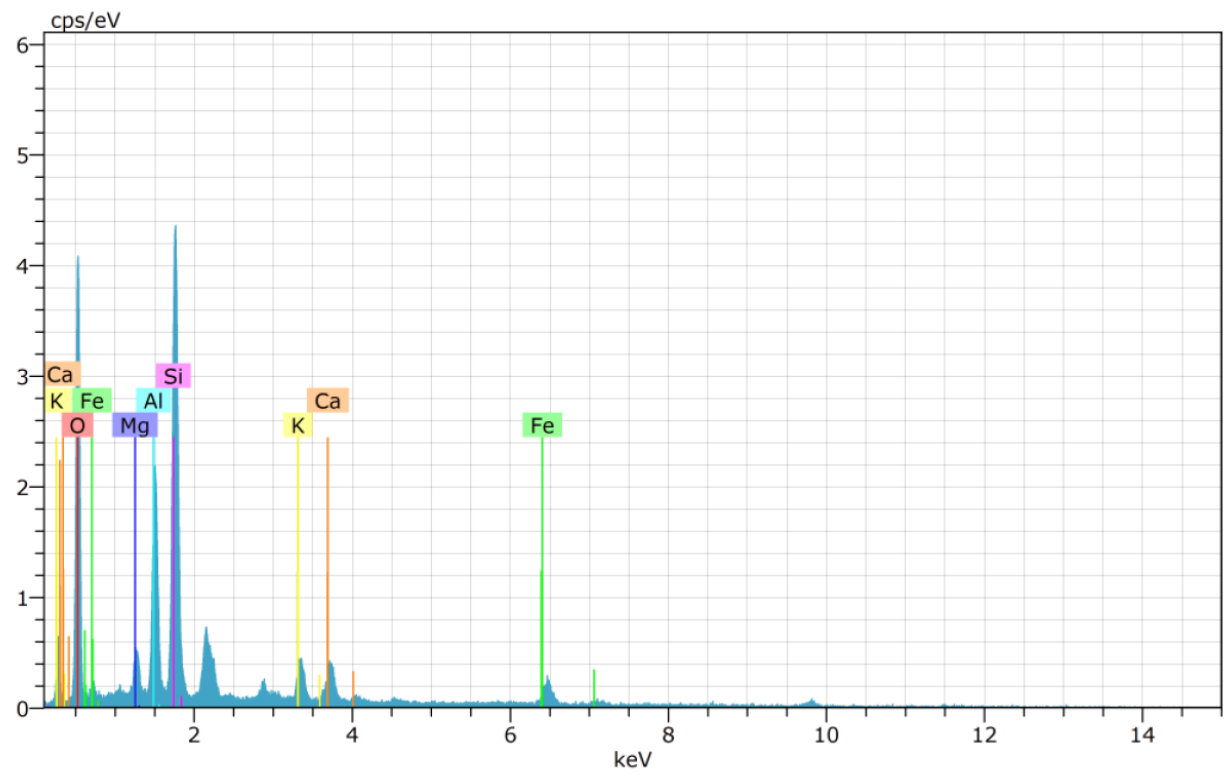

Şekil 5. Biyoçar:toprak oranının 5 olduğu örneğin 12. hafta sonundaki EDX spektrumu 


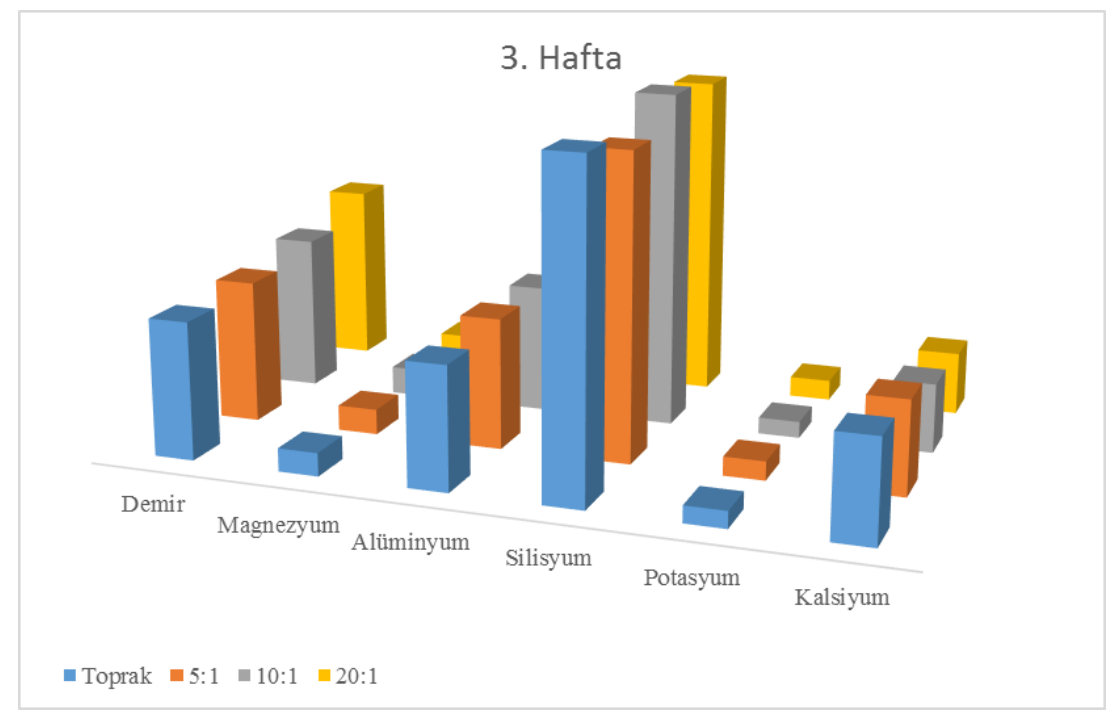

Şekil 6. Toprak ve biyoçar örneklerinin 3. hafta sonundaki inorganik elementlerin miktarı

Ağır metallerin biyoçar tarafından adsorbe edilmesi temel olarak, ağır metal ve biyoçarın fonksiyonel grupları arasındaki elektrostatik etkileşimlere dayanmaktadır [22]. Ağır metallerden alüminyum (Al) 3, 8 ve 12 . haftalarda her bir biyoçar:toprak oranı için azalmaktadır. Ağır metallerden bir diğeri olan demir (Fe) miktarı ise, 3 ve 8. haftada değişmezken, 12. haftada biyoçar:toprak oranı 20 olan örnekte azalmaktadır (Şekil 7, Şekil 8 ve Şekil 9). Elde edilen sonuçlar, ceviz kabuğundan elde edilen biyoçarın ağır metal kirlenmesine tabi olan toprakların iyileştirilmesinde kullanılabileceğini göstermektedir. Bitki beslemede, bitki için en gerekli olan elementler potasyum $(\mathrm{K})$, fosfor $(\mathrm{P})$ ve azot $(\mathrm{N})$ 'tur [6]. Bu elementlerden potasyumun inkübasyon süresi ve biyoçar:toprak oranına bağlı olarak miktarları incelendiğinde, 3,8 ve 12. haftalarda biyoçar:toprak oranının 5 olduğu örneklerde potasyum miktarının en yüksek seviyeye ulaştığı görülmektedir.

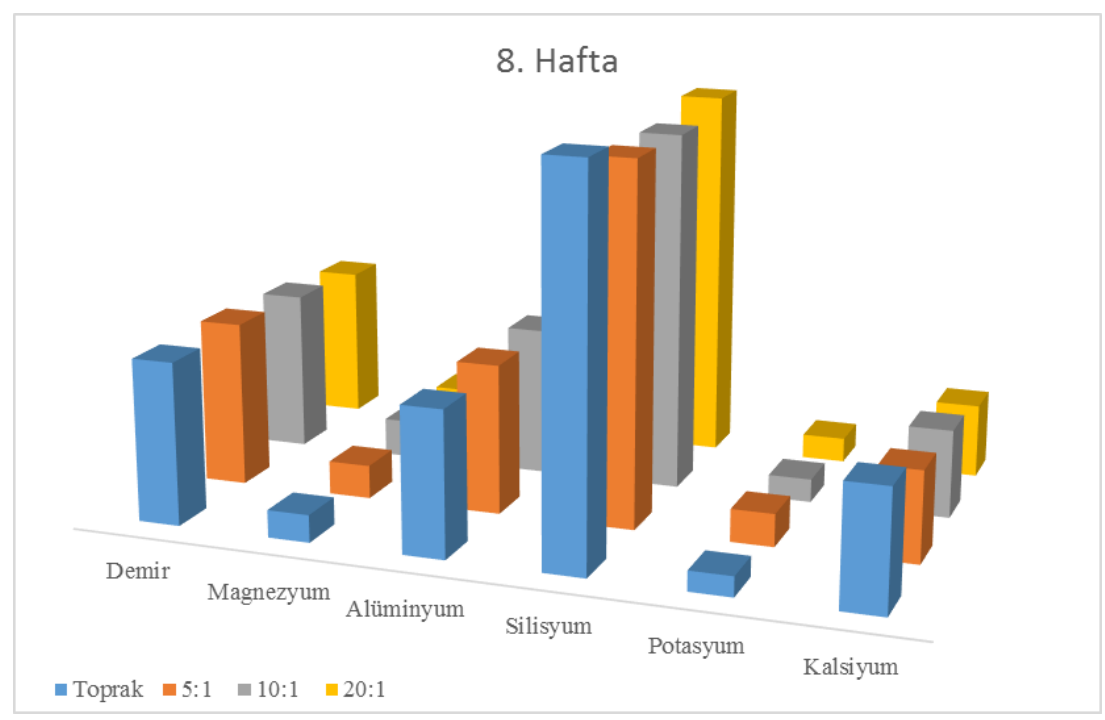

Şekil 7. Toprak ve biyoçar örneklerinin 8 . hafta sonundaki inorganik elementlerin miktarı 


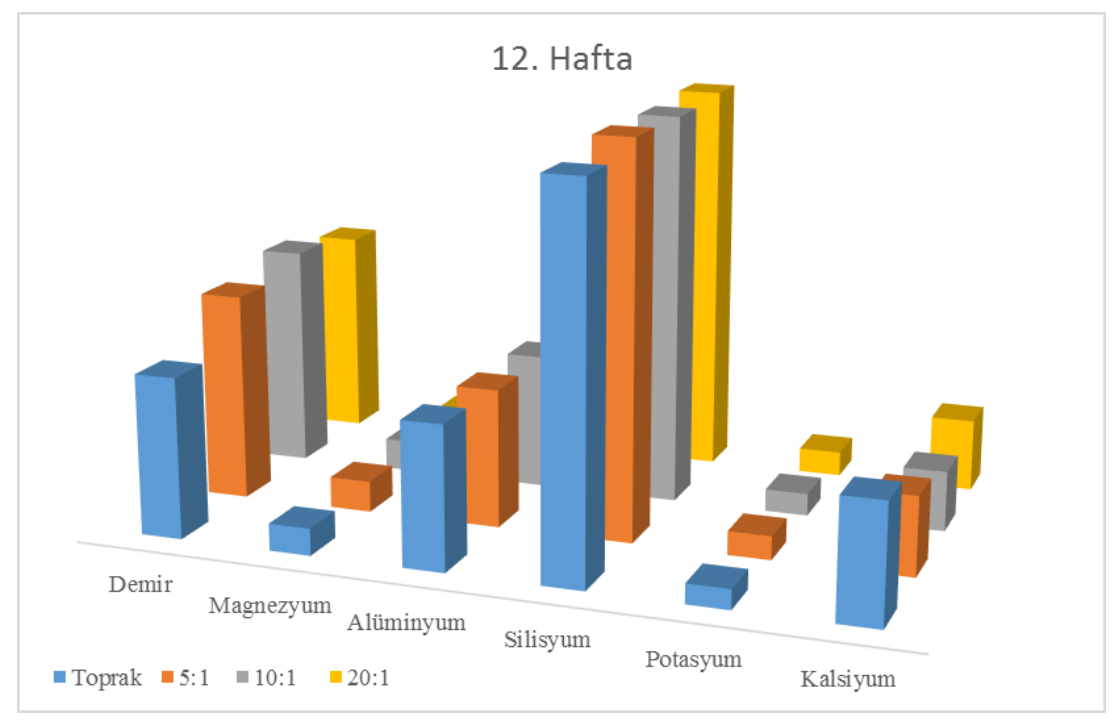

Şekil 8. Toprak ve biyoçar örneklerinin 12. hafta sonundaki inorganik elementlerin miktarı

Farklı oranlarda biyoçar içeren toprak örneklerinin 12. hafta sonunda gerçekleştirilen Kjeldahl analiz sonuçları Tablo 8'de verilmiştir. Elde edilen sonuçlara göre, toprak örneğine eklenen biyoçar miktarı arttıkça, toprağın önemli besin maddelerinden biri olan azot (N) miktarının arttığı belirlenmiştir.

Tablo 8. Biyoçar ve toprak örneklerinin Kjeldahl analiz sonuçları

\begin{tabular}{cc}
\hline Biyoçar $(\mathrm{g})$ : Toprak $(\mathrm{kg})$ oranı & Azot miktarı $(\%)$ \\
\hline $0: 1$ & $0,38 \pm 0,002$ \\
$5: 1$ & $0,74 \pm 0,010$ \\
$10: 1$ & $0,82 \pm 0,012$ \\
$20: 1$ & $0,90 \pm 0,08$ \\
\hline
\end{tabular}

\section{Bitki Büyüme Testleri Sonuçları}

Farklı oranlarda biyoçar içeren toprak örneklerine 12. hafta sonunda gerçekleştirilen roka bitkisi ekimi sonucu elde edilen bitki gelişimleri Tablo 9'de verilmiştir. Sonuçlar incelendiğinde en fazla boy uzaması ve en genişlemesinin biyoçar:toprak oranının 5 olduğunu örnekte görüldüğü ve topraktaki biyoçar miktarının artırılmasının büyümeyi etkilemediği belirlenmiştir. Bitki besleme için gerekli olan besin maddelerinden biri olan potasyum (K), SEM-EDX analiz sonuçlarına göre de biyoçar:toprak oranının 5 olduğunu örnekte en yüksek oranda belirlenmiştir (Şekil 7, Şekil 8 ve Şekil 9). Bu sonuç roka bitkisinin bu biyoçar:toprak oranında en iyi büyüme şartlarında olduğunu desteklemektedir. Literatürde, biyoçar uygulamasının bitki büyümesini olumlu etkilediği ve verimi artırdığı pek çok çalışma mevcuttur [23-25].

Tablo 9. Biyoçar miktarının bitki gelişimi üzerine etkisi

\begin{tabular}{|c|c|c|c|c|c|c|c|c|}
\hline \multirow{2}{*}{$\begin{array}{c}\text { Biyoçar }(\mathrm{g}): \\
\text { Toprak }(\mathrm{kg}) \\
\text { oranı } \\
\end{array}$} & \multicolumn{3}{|c|}{$0: 1$} & \multicolumn{2}{|c|}{$5: 1$} & \multicolumn{2}{|c|}{$10: 1$} & \multirow{2}{*}{$\begin{array}{l}20: 1 \\
\begin{array}{l}\text { Boy } \\
(\mathrm{cm})\end{array}\end{array}$} \\
\hline & $\begin{array}{l}\text { En } \\
(\mathrm{cm})\end{array}$ & $\begin{array}{l}\text { Boy } \\
(\mathrm{cm})\end{array}$ & $\begin{array}{l}\text { En } \\
(\mathrm{cm})\end{array}$ & $\begin{array}{l}\text { Boy } \\
(\mathrm{cm})\end{array}$ & $\begin{array}{l}\text { En } \\
(\mathrm{cm})\end{array}$ & $\begin{array}{l}\text { Boy } \\
(\mathrm{cm})\end{array}$ & $\begin{array}{l}\text { En } \\
(\mathrm{cm})\end{array}$ & \\
\hline 1.Yaprak & 1,2 & 2,3 & 1,8 & 5,6 & 0,9 & 2,8 & 1,2 & 1,8 \\
\hline 2.Yaprak & 1,6 & 3,2 & 2,9 & 5,9 & 1,2 & 2,6 & 1,6 & 3,6 \\
\hline 3.Yaprak & 1,1 & 2,4 & 2,4 & 5,4 & 1,3 & 2,2 & 0,8 & 2,2 \\
\hline 4.Yaprak & 0,9 & 1,8 & 2,2 & 4,8 & 1,5 & 2,9 & 1,2 & 2,3 \\
\hline 5.Yaprak & 0,4 & 2,1 & 1,9 & 4,9 & 1,9 & 2,2 & 0,7 & 1,6 \\
\hline Ortalama & 1,0 & 2,4 & 2,2 & 5,3 & 1,2 & 2,5 & 1,1 & 2,3 \\
\hline
\end{tabular}




\section{SONUÇ}

Çalışma kapsamında, biyokütleden biyoçar eldesi için karbon ve oksijen içeriği oldukça yüksek olan ceviz kabuğu kullanılmıştır. Öncelikle ceviz kabuğundan biyoçar elde edilmiş ve biyoçarın toprak iyileştiricisi olarak kullanılması amaçlanmıştır. Karbonizasyon süresince artan sıcaklık ile uçucu maddeler ceviz kabuğundan uzaklaşmış, $-\mathrm{OH}$ ve $\mathrm{C}-\mathrm{O}$ bağları kırılarak $\mathrm{C}=\mathrm{C}$ bağlarını içeren yapılar oluşmuştur. Karbonizasyon sonucu elde edilen katı ürünler kırılgan karbon içeriği yerine daha kararlı yapıda karbon içermektedir. Biyoçar yapısında bulunan karboksil grupları iyon değişim bölgeleridir ve toprak uygulamasında $\mathrm{pH}$ tamponlamada önemli bir rol oynamıştır. Karbonizasyon işlemi sonrasında biyoçar yüzeyinde elde edilen makro boyuttaki gözenekler ise toprağın su tutma kapasitesini iyileştirebilir niteliktedir. Biyoçar eklenmiş toprak örneklerinin elektriksel iletkenlik $(\mathrm{mS})$ ve $\mathrm{pH}$ değerleri inkübasyon süresi ve biyoçar miktarına göre incelendiğinde elektriksel iletkenlik ve $\mathrm{pH}$ değerlerinin azaldığı belirlenmiştir. Kjeldahl analizi yapıldığında toprak örneğine eklenen biyoçar miktarı arttıkça, toprak içerisindeki azot miktarının arttığı saptanmıştır. Biyoçarın bitki gelişimi üzerindeki etkisi incelendiğinde, en verimli sonuç $5 \mathrm{~g}$ biyoçar- $1 \mathrm{~kg}$ toprak karışımında elde edilirrken, topraktaki biyoçar miktarının artırılmasının bitki büyümesini önemli derecede etkilemediği belirlenmiştir. Bu çalışmanın sonuçları, biyoçar uygulamasının toprak özelliklerini iyileştirdiğini ve uygun koşullar sağlandığında roka bitkisinin büyümesini olumlu etkilediğini göstermiştir. Laboratuvar ölçeğinde yapılan bu çalışma tarla denemeleri ile geliştirilerek, sürdürülebilir kaynak olan biyokütleden elde edilen biyoçarın toprak düzenleyicisi olarak büyük ölçekte kullanılması sağlanabilir.

\section{KAYNAKLAR}

[1] Wall, D.H., Nielsen, U.N., Six, J. (2015). Soil biodiversity and human health. Nature, 528, 69-76.

[2] Nannipieri, P., Ascher, J., Ceccherini, M., Landi, L., Pietramellara, G., Renella, G. (2003). Microbial diversity and soil functions. European Journal of Soil Science, 54(4), 655-670.

[3] Khalil, H. A., Hossain, M. S., Rosamah, E., Azli, N. A., Saddon, N., Davoudpoura, Y., Y., Islam, M.N., Dungani, R. (2015). The role of soil properties and it's interaction towards quality plant fiber: A review. Renewable and Sustainable Energy Reviews, 43, 1006-1015.

[4] Chen, Z., Xiao, X., Chen, B., \& Zhu, L. (2014). Quantification of chemical states, dissociation constants and contents of oxygen-containing groups on the surface of biochars produced at different temperatures. Environmental science \& technology, 49(1), 309-317.

[5] Lal, R. (2015). Restoring soil quality to mitigate soil degradation. Sustainability, 7(5), 5875-5895.

[6] Yu, H., Zou, W., Chen, J., Chen, H., Yu, Z., Huang, J., Tang, H., Wei, X., Gao, B. (2019). Biochar amendment improves crop production in problem soils: A review. Journal of environmental management, 232, 8-21.

[7] Laird, D. A., Brown, R. C., Amonette, J. E., Lehmann, J. (2009). Review of the pyrolysis platform for coproducing bio-oil and biochar. Biofuels, Bioproducts and Biorefining, 3(5), 547-562.

[8] Kloss, S., Zehetner, F., Wimmer, B., Buecker, J., Rempt, F., Soja, G. (2014). Biochar application to temperate soils: effects on soil fertility and crop growth under greenhouse conditions. Journal of Plant Nutrition and Soil Science, 177(1), 3-15.

[9] Akgül, G. (2017). Biyokömür: Üretimi ve Kullanım Alanları. Selçuk Üniversitesi Mühendislik, Bilim ve Teknoloji Dergisi, 5(4), 485-499.

[10] Atkinson, C. J., Fitzgerald, J. D., Hipps, N. A. (2010). Potential mechanisms for achieving agricultural benefits from biochar application to temperate soils: a review. Plant and soil, 337(1-2), 1-18.

[11] Yuan, J. H., Xu, R. K. (2011). The amelioration effects of low temperature biochar generated from nine crop residues on an acidic Ultisol. Soil Use and Management, 27(1), 110-115.

[12] Kinney, T. J., Masiello, C. A., Dugan, B., Hockaday, W. C., Dean, M. R., Zygourakis, K., Barnes, R. T. (2012). Hydrologic properties of biochars produced at different temperatures. Biomass and Bioenergy, 41, $34-43$. 
Elif Yaman, Esin Apaydın-Varol, Hüseyin Tevfik Gültaş, Nurgül Özbay / BŞEÜ Fen Bilimleri, 6. Cilt - Prof. Dr. Fuat SEZGIN Bilim Y1lı Özel Sayısı, 106-116, 2019

[13] Yanai, Y., Toyota, K., Okazaki, M. (2007). Effects of charcoal addition on N2O emissions from soil resulting from rewetting air-dried soil in short-term laboratory experiments. Soil Science \& Plant Nutrition, 53(2), 181-188.

[14] Laird, D., Fleming, P., Wang, B., Horton, R., Karlen, D. (2010). Biochar impact on nutrient leaching from a Midwestern agricultural soil. Geoderma, 158(3-4), 436-442.

[15] Laird, D. A., Fleming, P., Davis, D. D., Horton, R., Wang, B., Karlen, D. L. (2010). Impact of biochar amendments on the quality of a typical Midwestern agricultural soil. Geoderma, 158(3-4), 443-449.

[16] Hurni, H., Giger, M., Liniger, H., Studer, R. M., Messerli, P., Portner, B., Schwilch, G., Wolfgramm, B., Breu, T. (2015). Soils, agriculture and food security: the interplay between ecosystem functioning and human well-being. Current Opinion in Environmental Sustainability, 15, 25-34.

[17] Thies, J. E., Rillig, M. C. (2009). Characteristics of biochar: biological properties. Biochar for environmental management: Science and technology, 85-105.

[18] Song, W., Guo, M. (2012). Quality variations of poultry litter biochar generated at different pyrolysis temperatures. Journal of Analytical and Applied Pyrolysis, 94, 138-145.

[19] EBC (2012). European Biochar Foundation (EBC), European Biochar Certificate-Guidelines for a Sustainable Production of Biochar, Version 6.1, Arbaz, Switzerland.

[20] Karla, Y. P. (1998). Reference methods for plant analysis, soil and plant analysis. Council. Inc.-CRC Press, Boca Raton, FL, 191.

[21] Uzun, B. B., \& Yaman, E. (2014). Thermogravimetric characteristics and kinetics of scrap tyre and Juglans regia shell co-pyrolysis. Waste Management \& Research, 32(10), 961-970.

[22] Lian, F., \& Xing, B. (2017). Black carbon (biochar) in water/soil environments: molecular structure, sorption, stability, and potential risk. Environmental science \& technology, 51(23), 13517-13532.

[23] Major, J., Rondon, M., Molina, D., Riha, S. J., Lehmann, J. (2010). Maize yield and nutrition during 4 years after biochar application to a Colombian savanna oxisol. Plant and soil, 333(1-2), 117-128.

[24] Qian, L., Chen, B., Chen, M. (2016). Novel alleviation mechanisms of aluminum phytotoxicity via released biosilicon from rice straw-derived biochars. Scientific reports, 6, 29346.

[25] Zhang, A., Liu, Y., Pan, G., Hussain, Q., Li, L., Zheng, J., \& Zhang, X. (2012). Effect of biochar amendment on maize yield and greenhouse gas emissions from a soil organic carbon poor calcareous loamy soil from Central China Plain. Plant and soil, 351(1-2), 263-275. 